\title{
The Institute of Oceanography and Fisheries in Split
}

\author{
A. Barić \\ Institute of Oceanography and Fisheries in Split; P.O. Box 500, 58000 Split, Croatia
}

\section{HISTORY}

The Institute was founded by an initiative from the Croatian Academy of Science in 1930 as the Biological Oceanographic Institute. This arose from the attitude that the Adriatic Sea could only be properly utilized as the basis for scientific research. The Biological Laboratory in Dubrovnik, a scientific unit of the Institute, was founded in 1950.

\section{ORGANIZATION OF THE INSTITUTE AND STAFF}

The research work is carried out by five laboratories covering the areas of marine physics, marine chemistry, marine biology, ichthyology and fisheries, and mariculture. The laboratory for marine physics carries out the research of the various aspects of seawater dynamics: currents, waves, and water-mass movements. Other physical properties of the sea, such as thermodynamics, optics and sea bed properties are also studied. The activity of the laboratory for marine chemistry is oriented around the research of basic hydrographic properties of the seawater: temperature, salinity, density, oxygen content, nutrient salts and heavy metals. The marine biological laboratory carries out research dealing with the structure and dynamics of planktonic and benthic communities. This research includes phytoplankton and primary production, zooplankton, bacterioplankton and phyto- and zoobenthos. The laboratory for ichthyology conducts research dealing with the structure and dynamics of pelagic and benthic fish species, in addition to ichthyoplankton. Different aspects of fisheries improvement, e.g. fishing technology, are also investigated. The mariculture laboratory studies the possibilities for optimal artificial fish rearing, particularly those dealing with different development stages. The present staff of the Institute consists of 82 members: 42 scientists, of which $17 \mathrm{PhD}$ 's, $22 \mathrm{MSc}$ 's and 7 undergraduates with BSc degrees are represented. Eleven technicians are employed in the laboratories. The rest are employees engaged in administrative jobs. Over the 60 year history of the Institute, the scientists have published about 1500 papers in both domestic and foreign journals.

\section{BUILDINGS AND EQUIPMENT}

The main building of the Institute has an area of $1123 \mathrm{sq} \mathrm{m}$. A series of well-equipped laboratories, a hatchery, a computer centre and a library are in the main building. In 
addition, there are several ancillary buildings, a meteorological-gauge station and a small port. The ancillary buildings cover about $1000 \mathrm{sq} \mathrm{m}$. The hatchery (an area of 250 sq $\mathrm{m}$ ), includes the space for larval and juvenile culture, for conditioning of parental stock and for phyto- and zooplankton culture. The hatchery has a total capacity of about $80 \mathrm{~m}$ and a recirculation system may be applied, employing the repeated use of seawater with pretreatment. This includes mechanical separation, biological processing through biofilters, thermoregulation and, finally, UV sterilization. For the experimental work, there is a special "wet" laboratory with 30 equal tanks, which can be supplied with both ambient seawater and recycled water. For supply and conditioning of the seawater, a pump has been installed at two depth levels, as well as a series of air pipes, compressors and a generator to provide a safe and continuous supply of electric current. In addition to standard laboratory equipment, laboratories are provided with the following necessary equipment: computer system (Iskra-Delta ADRIA 300/2; MicroVAX/II processor) with a 9 MB capacity, magnetic tape (1600 BPI); curve drawer (A3); curve digitizer (A3); automatic currentmeter (Aanderaa RCM4/S); tide gauge (Aanderaa WLR-2); tide gauge (A. Ott.); thermistor chain (Aanderaa TR-2); atomic absorption spectrophotometer (PerkinElmer 1100E); autoanalyzer (Technikon); polarograph; freeze dryer (WKF); gas chromatography (Varian GC 3400); spectrophotometer (PYE-UNICAM); fluorescence microscope (Zeiss); inverted microscope (Opton); interference microscope (Nomarki; Olympus BH-2).

\section{LIBRARY}

The library holdings have over 3700 book titles and over 800 reprints. The library receives 290 Croatian and foreign journals on an exchange basis; an additional 44 foreign journals are purchased. The receipt of about 260 journals has been cancelled, due to a shortage of storage capacity.

\section{RESEARCH VESSEL}

The research vessel "Bios" (property of the Institute), has the following characteristics: length $27.74 \mathrm{~m}$, width $7 \mathrm{~m}$, draught $2.8 \mathrm{~m}$, gross tonnage $173 \mathrm{BRT}$, area of the laboratories $38 \mathrm{sq} \mathrm{m}$, deck operating area $36 \mathrm{sq} \mathrm{m}$, maximum speed 12 knots, activity radius $3000 \mathrm{~nm}$, five crew members, and an extra boarding capacity for 16 scientists and technicians. The ship is provided with the following equipment: radar set (Decca 101 S); satellite navigator-transit system; ultrasonic speedmeter (Skipper CS-119); scientific sounder (Simrad); echo integrator (Mark II QM); net probe (Furuno); hydraulic winch hydrographic winch.

\section{PUBLICATIONS}

The journal "Acta Adriatica" has been published continuously since 1932. It publishes original scientific papers on the oceanography of the Adriatic and Mediterranean. Each paper was previously issued as a separate publication, but since 1979, has been issued as a single annual volume. Up to now, 2385 papers have been published in 28 volumes. The institute publishes a number of other editions: monographs - "Fauna and Flora of the Adriatic Sea" ; "Bilješke Notes" (up to now 52); "Report of the Fishery Biology from the 'HVAR' Expedition" (17 papers in nine volumes); special editions ( 7 books up to now); studies and technical papers (ca 100 various technical reports to date). 


\section{TEACHING ACTIVITIES AND TRAINING COURSES}

The scientific staff of the Institute give lectures at the postgraduate level of oceanography and at the undergraduate level in chemistry and biology. From time to time, courses are offered to students coming from different colleges all over our country. A three-month course (September-November) in fisheries for participants from developing countries has been held every year since 1981. Up to now, the course has been attended by 150 participants from African, Asian, Latin American and European countries. The programme includes the following topics on fisheries: fish stock assessment, oceanography, fishing technology, fish processing, fishery statistics and informatics.

\section{INTERNATIONAL COOPERATION AND COMMISSIONED RESEARCH}

International cooperation has been developed through a variety of aspects. From the very beginning of the Institute, the scientists have participated in the work of the International Commission for the Scientific Exploration of the Mediterranean (ICSEM). The vice president of this organization has always been elected from the Institute staff. From time to time, scientists of the Institute have been elected as presidents or vicepresidents of different committees.

Since its foundation, the Institute has been engaged in cooperation with different agencies of the United Nations. These include: General Fisheries Council for the Mediterranean (GFCM), Intergovernment Oceanographic Commission (IOC), World Meteorological Organization (WMO), Organization for Economic Cooperation and Development (OECD), United Nations Environmental Programme (UNEP).

The Institute has also developed bilateral cooperation with Italy, the USA, Greece and Poland. The Institute has also made a large number of studies and analyses on a contract basis with different organizations, firms, municipalities and Government of the Republic of Croatia. These are, in the first place, studies of environmental implications of various activities, monitoring of seawater quality, and fish stock assessment for commercial purposes.

\section{BIOLOGICAL LABORATORY DUBROVNIK}

The research activities in the Laboratory are mainly concerned with ecological aspects of the pelagic zone of the Adriatic Sea: planktonic biocoenoses and their composition, distribution and biomass all related to hydrographic, chemical and biologi$\mathrm{cal}$ parameters. Mariculture has also been developed: phyto- and zooplankton culture, the rearing of different fish stages and of shellfish. A part of the research work includes studies of flora and vegetation of the coastal belt along the mainland. The Laboratory staff number 32,14 of whom are scientists $(5 \mathrm{PhD}, 9 \mathrm{MSc})$. The library holdings amount to over 5000 reprints and over 1000 book titles.

The research vessel "Baldo Kostić" was destroyed during a Serbian attack on Dubrovnik.

The laboratories are equipped for ecological research with the following: stereo microscope; inverted, fluorescence microscope; spectrophotometer; calorimetric bomb; $\mathrm{T} / \mathrm{S}$ portable probe with 10 and $50 \mathrm{~m}$ cable; fish rearing experimental ponds with biofilter; thermostatic chamber for phyto- and zooplankton culture; thermostat; sterilizer. 
Teaching activities include lectures at undergraduate level for oceanography and at university level in field work for biology students from the University of Zagreb.

The Biological Laboratory has developed cooperation with different organizations and firms from the area of Dubrovnik, in the field of environmental protection, research for mariculture purposes, and ecological studies for the purpose of regional planning. The cooperation with international organizations is also well-developed, as is international cooperation with Italy.

For promoting public awareness of nature, there is an aquarium with 33 ponds, a natural-history collection with more than 4000 exhibits, and a botanical garden on Lokrum Island with an exceptionally valuable collection of eucalypti, acacias and pinetrees, from China, North and South America, Asia and Australia. 